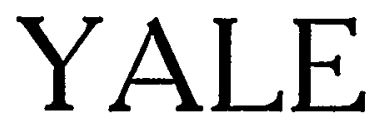

\begin{tabular}{lll}
\hline \hline Vol. XXIV NOVEMBER, 1914 No. 1 \\
\hline
\end{tabular}

\title{
THE CONSTITUTIONALITY OF STATUTES FOR- BIDDING ADVERTISING SIGNS ON PROPERTY
}

It has been held recently in a number of cases that laws forbidding advertising signs on property because they were unsightly or offensive to esthetic taste are unconstitutional as involving a taking of private property without compensation or depriving persons of their property without due process of law. ${ }^{1}$ It will not be necessary in this article to distinguish between "taking" and "depriving"; the two words will be treated as synonymous and either one used as may be convenient. I propose here to present an argument in favor of the constitutionality of such laws based on an analysis of the nature and scope of property rights.

In limine, I am one of those who strongly disapprove of the present prevailing tendency to limit the power of legislatures by multiplying constitutional restrictions or extending the scope of existing restrictions. Under our form of government the legislature, representing the people, is for ordinary purposes the appointed and the best law-making organ. We can not run such a government as ours without committing large powers to the legislature and trusting it not to abuse them. As President Wilson said, in government some one must be trusted. It is not the function of the constitution to prevent the legislature from doing every sort of foolish or wicked thing. In one of the cases cited above the court said that, if such statutes were

${ }^{1}$ Haller Sign Works v. Physical Culture Training School, 249 III. 436, 94 N. E. 920,34 L. R. A. (N. S.) 998; People v. Murphy, I95 N. Y. I26, 88 N. E. I7, 2 I L. R. A. (N. S.) 735; Conn. v. Boston Adv. Co., I88 Mass. 348, I08 Am. St. Rep. 494, 74 N. E. 60I, 69 L. R. A. 8I7. 
held valid every shopkeeper might be forbidden to put his name on the front of his store. Of course he might. So the legislature could repeal the laws for the collection of debts or the laws against theft or murder or do a thousand other foolish or wicked things. It is the business of the people to elect legislators who will not do so. The conditions of modern life require many regulations of conduct in the public interest that formerly could have been more advantageously left uninterfered with. I strongly deprecate a general attitude of distrust toward the legislature-even if to some extent it deserves it-and the establishment of rules, principles and precedents for the construction of constitutional prohibitions that tie up the legislature too tight, and may return to plague us by standing in the way of necessary and salutary regulations.

The decisions above mentioned stand on two propositions: (I) That forbidding such signs is in itself considered a taking of property, which can be constitutionally justified, if at all, only under what is called the police power of the state, and (2) That the laws in question are attempts to exercise the police power for purely esthetic purposes, to which that power does not extend, it being limited to guarding the public health, morals, comfort or general welfare.

With the second of these propositions I have nothing to do here. My purpose is to show that the first proposition is incorrect; that such a prohibition can be justified under perfectly well established legal principles, which apply to injurious acts generally independently of the police power and impose limitations of a more general sort on the use of property.

The word right has various meanings; there are several different kinds of rights, and it is necessary not to try to apply to one principles that are properly applicable only to another. Only two of those kinds of rights need here be considered, those to which I have elsewhere, for want of any generally accepted names, ventured to give the names of "permissive" and "protected" rights.

A permissive right is the legal condition of a person whom the law permits to do or abstain from an act, on whom the law lays no command as to that act. For convenience sake in the following discussion doing acts only will be mentioned. Abstaining from acts must be taken as embraced by the word "do." The act permitted may conveniently be called the content of the right. The act is not itself the right. The act is a fact, which might 
exist if there were no law; the right is a legal condition, the creature of the law. Such a right may or may not have a thing for its subject: $i . e$., the acts permitted may or may not be defined as acts affecting a thing. The rights of free speech and of religious liberty, which are among the most important of purely permissive rights, have no subjects; but rights of property, so far as they are permissive rights, are rights to do acts affecting things, and have such things for their subjects. Permissive rights of property are either (I) rights to take and hold possession of the thing ( $j u s$ possidendi), or (2) rights to use or deal with it. The owner of a thing may do whatever he pleases with it; a tenant for years has a large right of use, but must not commit waste; the holder of an easement may use the thing only in certain definite ways.

A permissive right can be exercised. The exercise of such a right means doing the act which forms its content. But it can not be violated. Violation of a right must be by the act of some person other than the holder of it; and ex definitione no other person's conduct is in any manner important in respect to the content of the right, only the conduct of the holder of the right himself. Where we speak of a right being violated, we mean some other kind of a right than a permissive right. It is true that the holder of a permissive right may be, even wrongfully, prevented from exercising it. But in that case the prevention, if wrongful, is affected by the violation of some other right of his. A person may be prevented from exercising his right of free speech by being bound and gagged. But then the interference with his body is a violation of his protected right of personal security. The wrong lies not in preventing him from speaking, but in the mere binding and gagging; that would equally be a wrong if he did not wish to speak at all. So if a person is ejected from his home and thus prevented from using it, the right violated is his protected right in the land or, if the ejectment is by actual violence, of his right of personal security.

A protected right is the legal condition of a person for whom the law protects a certain condition of fact. That condition of fact, not any act, is the content of the right. The most important of a person's purely protected rights is that of personal security, which comprises the sub-rights of life, bodily security, liberty, reputation and some others presently to be spoken of. The content of the right of bodily security is the condition of a person's body, which can be impaired, and the 
right violated, in two ways, namely, by contact of anything with the body, or where a battery is committed upon a person by merely touching without hurting him, and by changes in the condition of the body, as by wounds or those changes in the nervous system which manifest themselves in consciousness as bodily pain. The protected rights which are comprised in property are the right of possession (jus possessionis), whose content is the fact of being in possession of the thing which forms the subject of the right, which is violated by any interference with the possession, and a right in the physical condition of the thing, which is violated by any impairment of that condition.

A protected right can not be exercised, because ex definitione there is no act to be done or omitted by its holder. But it can be violated. The violation of a protected right means the impairment of the protected condition of fact, $e$. $g$. a change in the physical condition of a person's body or of a thing which he owns. Protection is given to rights by imposing duties upon other persons, whose due observance by them will prevent or tend to prevent the impairment of the protected conditions of fact. Different rights have different kinds of duties imposed for their protection; and the duties which are imposed to protect any particular right are said to correspond to that right. A violation of a right does not amount to a wrong unless it is caused by a breach of some duty which corresponds to that right. If $\mathrm{A}$ injures B's body by an intentional or negligent act, he breaks a duty that corresponds to the right of bodily security, and is guilty of a wrong; but if he injures him by mere accident, though B's right is just as much violated, there is no wrong, because no breach of duty. The word violation is generally used to denote only those impairments of protected states of fact which are wrongful, $i$. $e$. which are effected by such breaches of duty, so that the mere violation of a right is spoken of as a wrong. But I am here using the word in a wider sense to denote any impairment however caused.

The protected rights that will figure most largely in the following discussion are rights of mental security, which are subdivisions of the more general right of personal security. There is no general right of mental, as there is of bodily, security. Generally the law does not attempt to protect a person from purely mental injuries, such as fright, mortification or anxiety. As a general rule it is not a tort to frighten or insult a person, even intentionally. - But the law does recognize and protect cer- 
tain limited rights of mental security. The right that is violated in an assault without a battery is such a right, whose content is the mental condition of freedom from apprehension of immediate violence. Also when some other right has been violated, e. $g$. the right of bodily security by a battery, additional damages may sometimes be recovered for mental suffering, which makes it necessary to posit what may be called an ancillary right of mental security, which cannot be separately violated even to give a cause of action but can be violated in connection with other rights. Some other rights of mental security of a limited scope will be mentioned hereafter. It is enough to say here, that although the law does not protect a person's state of mind generally, it does so in some cases; the principle that states of mind as well as bodily states may form the contents of protected rights whose violations may amount to wrongs, is and always has been recognized in our law.

The right of property is a complex group of rights comprising both permissive and protected rights, as has been said above, in which respect it differs from such rights as that of free speech, which are purely permissive, and of personal security, which are purely protected rights.

The taking of property which is forbidden by the constitution means either of three things, namely: (I) Depriving a person of his property right, so that he no longer has any such right at all; (2) violating his protected right of property by some physical interference with the thing owned; (3) preventing him from exercising his permissive rights in ways in which he might otherwise have lawfully exercised them, and thus narrowing the content of those rights.

If forbidding advertisements on property is a taking of the property, it is so only in the third of the above-mentioned ways; therefore the first and second need not be further noticed.

This makes it necessary to consider somewhat more fully exactly what is meant by the exercise of a right. As has been said, the exercise of a right means doing the act that forms the content of the right, that very act and no other. But an act is a mere bodily movement, which in and of itself is never of any legal importance. Such bodily movements are important only if and in so far as they produce certain consequences. Acts are defined for legal purposes by reference to some of their consequences, both in the definitions of duties and of permissive rights. The duty not to commit a battery, for instance, is not not to do 
any act, not to make any bodily movement, which will produce as its direct consequence the contact of something with the body of the other party. It makes no difference what the act is, a battery may be committed by any one of a thousand different acts; it is the production of the consequence that is forbidden. So in defining the acts which a tenant or bailee may or may not do in the use of the thing which he holds, we define the consequences which he may or may not produce upon the thing. He may not commit waste; and when we come to define waste we do so by describing certain effects which may not be produced upon the thing, not by describing the bodily movements by which those effects can be produced. The consequences by reference to which acts are described for the purpose of defining duties or permissive rights may conveniently be called the definitional consequences of the act or of the duty or right. In duties the definitional consequences may be actual or only probable or intended consequences of the act; in permissive rights of property they are actual consequences. An act done in the exercise of a right, besides producing consequences which are definitional of the right, may also produce other consequences which are not definitional. This distinction between definitional and non-definitional consequences, both resulting from the same act, is of the utmost importance. In the case of property rights, which are rights in things, which have things for their subjects, the only consequences which are definitional of the right are consequences produced upon the thing itself, changes in the position or condition of the thing. Consequences produced upon persons or upon other things are not definitional consequences of the right, though their production may be rightful for other reasons. If, for instance, the owner of a gun rightfully shoots a wild deer, the movements of the gun and its parts in aiming and firing, the explosion of the powder and the flight of the ball, all of which things are his property, are definitional consequences of his right; his property right includes a right to use the gun, powder and ball in that way, to produce those effects upon them. But the contact of the ball with the deer's body and the death of the deer, though consequences which he may lawfully produce, are not definitional of his property right in the gun or the powder or even in the ball. Whether he may lawfully shoot the deer does not depend at all upon his property right in the gun-the question would be the same had he taken another man's gun without the owner's leave-but upon whether he is subject to any duty, e. $g$. 
under the game laws, not to do so. If there were such a duty, the effects produced upon the deer would be definitional of that duty, and of the acts done by him in shooting with reference to that duty, but not of his property right or of those same acts with reference to that right. The same consequences produced by an act may therefore be definitional of the act for one purpose, for defining one particular right or duty, but not for another; and different consequences produced by it may be definitional for different duties or rights.

To exercise a right means to produce the consequences that are definitional of the right, no others. An act done to exercise a right is an exercise of it only if and in so far as it produces such consequences; so far as it produces non-definitional consequences, it is not an exercise of the right at all. "A distinction must be made between an act done in the exercise of a right and an act that is an exercise of a right; or rather, since it is one and the same act, between two different aspects of the act. To recur to the example just mentioned of shooting a deer, the bodily movements by which the gun is aimed and fired are exercises of the property right in the gun so far as their effects upon the gun are concerned, but as to their effects upon the deer they are not exercises of that right, though done in the course of its exercise. An illustration of the confusion that prevails on this point may be found in the case of Detroit Base Ball Club v. Deppert. ${ }^{2}$ The plaintiffs had a baseball ground, and made profits from the fees which they charged for the admission of spectators. The defendant built on his own adjoining land a stand from which the games could be seen and admitted spectators to that, thus reducing the plaintiff's gains. This was held not to be a tort, because the defendant was only exercising his property right in his own land. The decision was right, but that reason for it was wrong. So far as the defendant's acts produced consequences on his own land, $i$. $e$. the presence of structures and spectators there, they were an exercise of his property right. But the plaintiffs' loss of profits, which was the only consequence that was injurious to them, was not a definitional consequence of that right, and in connection with that consequence the acts were not exercises of the defendant's right at all. The true ground of the decision was that the defendant did not break any duty which he owed to the plaintiffs. There

${ }^{2} 61$ Mich. 63, I Am. St. Rep. 566, 27 N. W. 856 . 
is no general duty not to do acts which cause pecuniary loss to another, though there are some duties of that sort of a limited scope, chiefly when the acts are done fraudulently or maliciously.

An act done in the exercise of a right may in connection with consequences of it which are not definitional of the right be a breach of duty; and if it produces non-definitional consequences which amount to a violation of a protected right, it may be a tort-to make a tort both a breach of duty and a resulting violation of some protected right to which the duty corresponds are necessary. This is the meaning of the maxim, sic utere tuo ut alienum non laedas, so far as that famous maxim has any definite meaning: in exercising your own permissive rights do not produce non-definitional consequences which are violative of the protected rights of others. In the above example of shooting a deer, the deer being res mullius, the effects produced upon it were not violative of any right. But if the animal shot had been a neighbor's cow, the same sort of effects produced upon the cow would have been a violation of her owner's property right in her, and the act of shooting, though done in the exercise of a right in the gun, would have been a breach of duty, and the shooting a tort. So if a libel is printed in a newspaper, the existence of the printed sheet and its delivery to a buyer are definitional consequences of the publisher's property right in the printing press, paper and ink, and as to those consequences the printing and sale of the paper are exercises of that right. But the effect of those same acts upon the reputation of the person libeled is not a definitional consequence, it is vioative of the latter person's protected right of reputation, and the publication is a tort.

It follows that when we say that the owner of a thing may do whatever he pleases with it, that statement is true only so far as relates to definitional consequences of his acts produced upon the thing itself. As to other consequences of such acts, every right of property is limited by the existence of protected rights of others and by duties not to produce non-definitional consequences violative of such rights. The more protected rights others have, the narrower are the limits within which the holder of a property right is practically able to exercise his right. If the state creates a new kind of protected right, that at once, ipso facto, irrespective of any question as to the police power, under a principle of law of great generality, practically narrows the scope of the exercise of the permissive rights of other per- 
sons. If, for instance, the state should make wild deer private property, then certain acts done in the exercise of property rights in guns, which before were lawful, would become unlawful, would be breaches of duty and violative of the new right; or if it should be made libelous to call a man in print a Jew, the property rights of newspaper publishers could not be exercised without committing a wrong in certain cases where they could have been before the right of reputation was thus enlarged. But nobody, I suppose, would assert that the mere creation of a new kind of protected rights, by whose existence the scope of the exercise of permissive rights was thus narrowed, would amount to a taking of such permissive rights, whether they were permissive rights of property or some other kind of permissive rights.

Statutes forbidding advertisements on property would create a new kind of protected right, another limited right of mental security, which may be conveniently called a right of esthetic security. The state now undertakes to protect a state of mind consisting in freedom from annoyance from certain hideous objects, which formerly it did not protect. If such a right is created, the same principle must necessarily apply to it as to other protected rights, that in doing acts in the exercise of permissive rights non-definitional consequences must not be produced which will be violative of the right. Its existence practically limits the exercise of permissive rights in precisely the same way and on precisely the same principles as the existence of any protected right limits it, and not otherwise. There is no occasion to invoke the police power, unless all the cases that fall under the maxim sic utere tuo, practically the entire law of wrongs, be considered to depend upon that power. There is no direct interference with the exercise of permissive rights at all. Such rights may still be exercised, so far as the production of definitional consequences is concerned, as fully as before. No act which was before an exercise of a right is as such forbidden. The new law affects acts done in the exercise of permissive rights in relation to their consequences which are not definitional of the rights. The interference with the exercise of rights is only indirect and incidental. But it has often been held in construing constitutional provisions against taking private property that indirect and incidental damage to property, not amounting to a violation of the protected right in it by a physical interference with it, does not constitute a taking. It is to cover this act of damage that some constitutions have provided that property shall 
not be taken or damaged without compensation, damage being distinguished from taking.

The point upon which the constitutionality of the statutes in question depends is therefore not whether the police power can be exercised for esthetic purposes, but whether the legislature has the power to create new kinds of protected rights, or new kinds of rights of mental security. It seems to me that it would be a false and dangerous principle of constitutional interpretation, and one that would go far beyond the true intent of the constitution, that would deny such a power to the legislature or would leave it to the courts to decide what protected rights ought to exist. That is a question of policy which lies peculiarly within the province of the legislature. The fact that the legislature has acted unwisely and unreasonably, or even arbitrarily, unjustly or tyrannically, in creating a new kind of protected right is one with which the courts have no concern. It is the people who elect the legislature who must correct and protect themselves from its bad legislation, so long as it confines itself within the limits of the powers which the people have given it.

It will not, I think, be questioned, that the legislature can create by statute any sort of new rights which the courts can by the powers of judicial legislation. But the courts have created lately various rights of mental security which were unknown to the old law. One of those is a husband's right in the affection of his wife, which, if not in the strict sense a right of mental security, is at least of a similar nature. A husband may now have an action for alienating his wife's affection. The old common law, I think, gave no such action when the wife was not led so far as to adultery. But the courts have considered that the conditions of modern life and society require the recognition of such a right of the husband's, as well as a similar right of the wife's. The best example is the entirely new right of privacy. That is undoubtedly a right of mental security. In most places no such right is yet recognized. But a right of that kind, not as yet very well delimited, is recognized and protected in some of the states; and even when it is not, the refusal to recognize it has been put, so far as I now remember, on the ground of the lack of precedents, rather than on that of unconstitutionality. ${ }^{3}$

${ }^{3}$ DeMay v. Roberts, 46 Mich. I60, 4r Am. Rep. 154, 9 N. W. I46; Foster-Welburn Co. v. Chinn, I34 Ky. 424, I35 Am. St. Rep. 4I7, I20 S. W. 364,34 L. R. A. (N. S.) II37; Munden v. Harris, I33 Mo. App. 
I suppose there can be no doubt that the legislature could make it actionable to frighten a person, even though no bodily injury ensued, or to insult him, thus creating new rights of mental security, and could none the less do so, though the frightening or insulting was done by the use of property, e. $g$. by posting insulting, though not libelous, placards on property. If then the legislature has power to create new rights of mental security, the existence of which may practically limit the exercise of permissive rights or the use which may be made of property, why may it not create a right of esthetic security whose existence will have precisely the same kind of effect?

I am quite aware that the foregoing argument carries far enough to empower the legislature to forbid any use of property or any acts done in the exercise of permissive rights, which produce non-definitional consequences affecting other persons which the legislature thinks ought not to be produced-unless perhaps the legislative act is done palpably in bad faith, the real intent being plainly to prevent definitional consequences, or unless the prohibition is so extensive as practically to prevent any exercise of the permissive right at all, or any reasonable or beneficial exercise of it, and so amount virtually to confiscation. But no such objection can be made against the statutes now in question. In the case of certain vague permissive rights which have no subjects, such as the right of free speech, perhaps that line of argument would not apply.

NeW YoRK CITY.

HENRY T. TERRY.

652, I24 S. W. 1076; Itzkovitch v. Whittaker, II5 La. 479, I12 Am. St. Rep. 272, 39 So. Rep. 499, II7 La. 708, II6 Am. St. Rep. 215, 42 South. 228. 